\title{
Performance evaluation of rapeseed mustard under rice fallow system for optimizing productivity, profitability and resource conservation
}

\author{
KHUMLO LEVISH CHONGLOI* AND DEEPAK SINGH
}

\begin{abstract}
The study was conducted in Chandel district of Manipur state to maximise the productivity of Rapeseed-mustard under rice fallow. Rapeseed-mustard has great potential under residual moisture after the harvest of Kharif rice in North Eastern states. It is a major source of income especially to the marginal and small farmers in rainfed areas of Manipur. Sample consisted of randomly selected 29 farmers who were growing rapeseed-mustard under FLDs. The results revealed that improved technology recorded a mean yield of $8.77 \mathrm{q} /$ ha which was 20.55 per cent higher than obtained under farmers' practice ( $7.27 \mathrm{q} / \mathrm{ha}$ ). The study also showed that reduction in technology index from 10.90 per cent during 2017-18 to 6.49 per cent during 2019-20 exhibited the feasibility of demonstrated technology. The lower value of technology index, the more is the feasibility of technology. Further, it was found that the adoption of improved technologies not only increased the yield but also yield attributing traits of rapeseed-mustard and benefit cost ratio. Hence, there is a need to disseminate the improved technologies amongst the farmers with effective extension methods like training and demonstrations to utilise the rice fallow areas for increasing the cropping intensity as well as to increase crop production and productivity. The farmers' should be encouraged to adopt the recommended package of practices for realizing higher returns.
\end{abstract}

KEYWORDS

Rice fallow, Front Line Demonstration, Rapeseed-mustard.

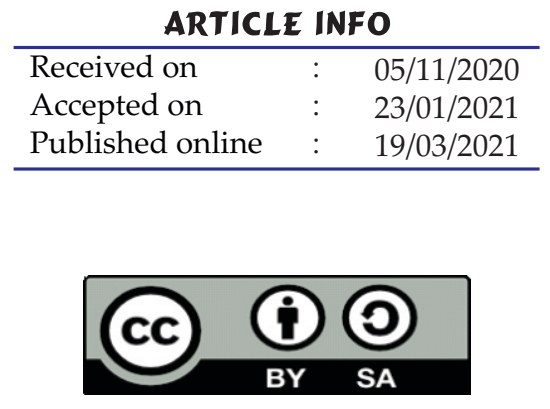

\section{INTRODUCTION}

$\mathrm{I}$ $\mathrm{n}$ India, about $11.7 \mathrm{~m}$ ha area of kharif rice remains fallow in the subsequent rabi due to number of biotic, abiotic and socio-economic constrains (Ghosh et al., 2012). Rice fallows basically imply to those low lands kharif sown rice areas which remained uncropped during rabi (winter) season due to various reasons such as lack of irrigation, cultivation of long duration varieties of rice, early withdrawal of monsoonal rains leading to soil moisture stress at planting time of winter crops, water logging and excessive moisture in November/December, lack of appropriate varieties of winter crops for late planting and stray cattle menace etc. (Ali, 2014). Rapeseed-mustard on account of low input requirements, short duration, ability to establish with surface broadcast and soil fertility restoration property are ideal for rice fallows. It was realized that ricefallow cropping system may be substituted by introducing short duration oilseed crops like toria (Brassica campestris var. toria) along with other possible measures with the hope that toria will not only provide additional yield coupled with better land use efficiency but also will help the resource poor the tribal farmers of the region in improving the livelihood and nutritional security. Minimum soil traffic by adoption of suitable technology involving no-tillage and minimum soil disturbance and management of crop residues could lead to favourable effect on soil properties that further enhance the

ICAR-KVK, Chandel, MonsangPantha, ICAR Research Complex for NEH Region, Manipur Centre, Imphal, India

*Corresponding author email : levischongloi@gmail.com overall resource use efficiency and productivity capacity in rice-fallows. Productivity and profitability from second crops in rice fallow can be improved with suitable crop management technique even by utilizing residual soil moisture. Choice of appropriate crops and varieties, introducing early to medium duration varieties of rice to enable farmers to grow oilseeds on residual moisture in time. Taking the above into consideration, a Front-Line demonstration on Rabi oil seeds was conducted at the farmer's field of Chandel district with the objective to establish an oil seed crop (rapeseed-mustard) in rice-fallow system. The front-line demonstration (FLD) is an important method of transferring the latest package of practices in totality to farmers. Further, these demonstrations are designed carefully where provisions are made for speedy dissemination of demonstrated technology among farming community through organization of other supportive extension activities, such as field days and farmers convention (Meena and Dudi, 2018).

\section{MATERIALS AND METHODS}

The study was carried out in the district of Chandel during Rabi 2017-18, 2018-19 and 2019-20. A total of 41 FLDs were conducted at farmers' field in 35-hectare area. The package of improved technologies like line sowing, nutrient management, seed treatment and whole package were used in the demonstrations. The Rapeseed-mustard variety TS-36 was demonstrated and local variety Yella was taken as farmers' practices. In general, soils of the area under study were clay 
loam and medium to low in fertility status. The seeds of rapeseed-mustard were sown in rice fallows, thinning and weeding was done invariably 30-35 days after sowing to ensure recommended plant spacing within a row because excess population adversely affects growth and yield of crop. Sowing was done in the first week of Nov with a seed rate of 10 $\mathrm{kg} / \mathrm{ha}$. The data on plant parameters and economic yield and economic returns from FLD plots and from fields and local practices adopted by the farmers were collected and evaluated. Technology index can also be calculated as given by (Meena and Dudi, 2018)

Technology index $=\frac{\text { Potential yield }- \text { Demonstration yield }}{\text { Potential yield }} \times 100$

\section{RESULTS AND DISCUSSION}

\section{Yield attributing traits}

The data on different yield characters were recorded from different FLD plots. The numbers of siliqua per plant under demonstrated field were 130.80, 132.40 and 133.00 as against farmers' practise $123.35,125.60$ and 126.15 (Table 1) during the year 2017-18, 2018-19 and 2019-20. There was an increase of $6.03,5.41$ and 5.43 per cent of number of siliqua under demonstration of improved technology using improved variety TS-36 over farmers' practice i.e. growing of local variety Yella. The numbers of seeds per siliqua under demonstration were also higher than the farmers practice during the three years of demonstration. The findings are close confirmation with the findings of Singh et al., 2013 and Kumar, 2015.

Table 1: Yield attributing characters of rapeseed-mustard var. TS-36

\begin{tabular}{l|cccccc}
\hline \multirow{2}{*}{ Parameters } & \multicolumn{3}{|c}{ Demonstrated } & \multicolumn{3}{c}{ Farmers practice } \\
\cline { 2 - 7 } & 2017-18 & $\mathbf{2 0 1 8 - 1 9}$ & $\mathbf{2 0 1 9 - 2 0}$ & $\mathbf{2 0 1 7 - 1 8}$ & $\mathbf{2 0 1 8 - 1 9}$ & 2019-20 \\
\hline $\begin{array}{l}\text { Plant } \\
\text { height } \\
\text { (cm) }\end{array}$ & 74.33 & 75.45 & 75.50 & 73.40 & 74.12 & 74.25 \\
$\begin{array}{l}\text { No. of } \\
\text { siliqua/ } \\
\text { plant }\end{array}$ & 130.80 & 132.40 & 133.00 & 123.35 & 125.60 & 126.15 \\
$\begin{array}{l}\text { No. of } \\
\text { seeds/ } \\
\text { siliqua }\end{array}$ & 6.25 & 6.80 & 7.00 & 5.12 & 5.5 & 5.70 \\
\hline $\begin{array}{l}\text { Test } \\
\text { weight (g) }\end{array}$ & 4.12 & 4.32 & 4.33 & 4.0 & 4.10 & 4.12 \\
\hline
\end{tabular}

\section{Seed yield}

The yield of rapeseed-mustard under FLDs were recorded to be $8.50 \mathrm{q} / \mathrm{ha}, 8.90 \mathrm{q} / \mathrm{ha}$ and $8.92 \mathrm{q} / \mathrm{ha}$ during 2017-18, 2018-19 and 2019-20 with the mean yield of $8.77 \mathrm{q} /$ ha (Table 2). The increase in yield under improved technology was $18.38 \%$, $21.91 \%$ and $21.36 \%$ during 2017-18, 2018-19 and 2019-20 respectively against the increase in yield under farmer's practise. The increased yield with improved technologies was
Table 2: Seed yield of rapeseed-mustard under FLD and Farmer practise (FP)

\begin{tabular}{c|cccc}
\hline \multirow{2}{*}{ Year } & \multirow{2}{*}{$\begin{array}{c}\text { Area } \\
\text { (ha) }\end{array}$} & $\begin{array}{c}\text { Demonstrations } \\
\text { (No.) }\end{array}$ & \multicolumn{2}{c}{ Yield (q/ha) } \\
\cline { 4 - 5 } & & & Demonstration & $\begin{array}{c}\text { Farmers } \\
\text { practise }\end{array}$ \\
\hline $2017-18$ & 20 & 14 & 8.50 & 7.18 \\
$2018-19$ & 5 & 15 & 8.90 & 7.30 \\
$2019-20$ & 10 & 12 & 8.92 & 7.35 \\
\hline Average & 11.66 & 13.66 & 8.77 & 7.27 \\
\hline
\end{tabular}

mainly because of the scientific package of practices and use of improved variety seed.

\section{Technology index and economics}

Reduction in technology index from 10.90 per cent during 2017-18 to 6.49 per cent during 2019-20 exhibited the feasibility of demonstrated technology (Table 3). The lower value of technology index, the more is the feasibility of technology (Bharati et al., 2014). The difference in technology index during the study period might be attributed to the dissimilarity in soil fertility status, weather conditions, nonavailability of soil moisture and insect pest attack in the crop. Mitra and Samajdar (2010) opined that lower the value of technology index more is the feasibility of the technology demonstrated. Hence, it can be inferred that the awareness and adoption of improved varieties with recommended scientific package of practices have increased during the advancement of study period.

Table 3: Technology index of rapeseed-mustard under FLD and Farmer practise (FP)

\begin{tabular}{c|cccc}
\hline Year & $\begin{array}{c}\text { Increase in } \\
\text { yield (\%) }\end{array}$ & $\begin{array}{c}\text { Potential } \\
\text { Yield (kg/ha) }\end{array}$ & $\begin{array}{c}\text { Technology } \\
\text { Index (kg/ha) }\end{array}$ & B:C ratio \\
\hline $2017-18$ & 18.38 & 9.54 & 10.90 & $1.82: 1$ \\
$2018-19$ & 21.91 & 9.54 & 6.70 & $1.90: 1$ \\
$2019-20$ & 21.36 & 9.54 & 6.49 & $1.91: 1$ \\
\hline Average & 20.55 & 9.54 & 8.03 & $1.87: 1$ \\
\hline
\end{tabular}

\section{CONCLUSION}

The two years study from front line demonstrations convincingly brought out that the rice fallow land can be utilised for enhancing resource use efficiency and also yield of rapeseed-mustard could be increased by $18.38 \%$ to $21.36 \%$ with the intervention on scientific package of practices and use of improve variety seed. From the above findings, it can also be concluded that use of scientific methods of rapeseed-mustard cultivation can reduce the technology index to a considerable extent thus leading to increased productivity in the district. Scientific cultivation practices with improve variety rapeseed-mustard could help in improving oilseed productivity under challenging rice fallow conditions. Favourable benefit cost ratio itself explanatory of economic viability of the demonstration and convinced the farmers for adoption of intervention imparted. 


\section{REFERENCES}

Ahmed P, Nath RK, Sarmah AC and Deka PC. 2017. Yield Gap Analysis of Toria (Brassica campestris) in Tinsukia District of Assam. Indian Res. J. Ext. Edu. 17 (3): 44-46.

Ali M. 2014. Improving productivity of pulses in rice fallows. Indian Farming (63): 12: 17-19.

Bharati RC, Singh KM, Chandra N and Singh AK. 2014. Economic condition of eastern region of India -An statistical evaluation. Journal of AgriSearch 1(3):173-179.

Ghosh PK, Kumar N, Hazra KK and Venkatesh MS. 2012. Carrying capacity of untrapped rice fallows for pulse production. In proceedings of 3rd International Agronomy Congress, November 26-30, 2012, New Delhi.Vol. 1. Indian Society of
Agronomy, New Delhi, India. Pp. 61-62.

Kumar R. 2015. Effects of NPKS on growth, yield and quality of late sown toria varieties (Brassica rapa. var. toria) under rainfed condition of North East India. Bangladesh J. Bot.44(4): 521-528.

Meena M L and Dudi A. 2018. Increasing Greengram Production through Frontline Demonstrations under Rainfed Conditions of Rajasthan. Journal of Krishi Vigyan 7(1) : 144-148.

Mitra B and Samajdar T. 2010. Yield gap analysis of rapeseed-mustard through Front Line Demonstration. Agri. Ext. Review: 16-17.

Singh AK, Singh KA, Bharati RC and Chadra N. 2013. Response of intercrops and nutrient management on the performance of tobacco based intercropping system and assessment of system sustainability. Bangladesh J. Bot. 42(2): 343-348.

Citation:

Chongloi KL and Singh D. 2021. Performance evaluation of rapeseed mustard under rice fallow system for optimizing productivity, profitability and resource conservation. Journal of AgriSearch 8(1): 59-61. 